\title{
MANAGING DISRUPTIVE INNOVATION: ENTREPRENEURIAL STRATEGIES AND TOURNAMENTS FOR CORPORATE LONGEVITY
}

\author{
Yanto Chandra \\ Shu-Jung Sunny Yang * \\ Leeds University Business School \\ Essex Business School
}

26 November 2011

Forthcoming in Journal of General Management

\begin{abstract}
Extant research on disruptive innovation has implicitly incorporated entrepreneurship as the underlying driver of the disruptive phenomenon. We integrate recent developments from entrepreneurship and innovation research streams to better understand the conditions and causal mechanisms that influence disruptive innovation. Drawing on effectuation, evolutionary entrepreneurship, lead-users, collective intelligence, and opportunity tournament literature, we develop a theoretical framework that explains disruptive innovation as a co-evolutionary entrepreneurial process at the firm, product, and customer level. The framework offers a set of testable propositions to advance theory and practice in the field. We suggest avenues for future research and conclude entrepreneurial strategies to help general managers create and cope with disruptive innovation.
\end{abstract}

Keywords: Disruptive Innovation, Entrepreneurship, Effectuation, Lead Users, Collective Intelligence, Opportunity Tournaments

\section{INTRODUCTION}

The rise and fall of firms in high technology industries under the umbrella of disruptive innovation has been a theme of inquiry that fascinates many scholars in economics, technology management, strategy, and among others, from the neoclassical period (Schumpeter, 1934a, 1934b, 1939) to the contemporary management era (e.g. Dosi, 1982, Christensen, 1993, 1997, 2006; Collins, 2001; Foster and Kaplan, 2001; Adner, 2002). While the business history is replete with examples of successful firms and their superior products replaced by competitors and new entrants with less superior products, there is a scant attention on what CEOs and general managers can do to better create and cope with disruptive innovation. Disruptive innovation reflects the boom and bust of market economy and has

\footnotetext{
*Corresponding author. Contact: sunnyy@essex.ac.uk or sj.sunny.yang@gmail.com (S.-J. S. Yang).
} 
occurred across a wide range of products and industries, including the fast transition from chemicalbased to digital films, analogue to digital and to high-definition televisions; the use of nanotechnology-based devices for cancer treatment, and from fossil fuel to renewable energy. Importantly, the frequency of such 'discontinuities' is increasing (Adner, 2002).

While research on disruptive innovation has flourished in the past decades, this has generally focused on the nature and characteristics of the innovation, and its influencing factors to some extent. Specifically, little is understood about how and why disruptive innovation occurs and, ultimately, what CEOs and general managers can do to better managing the process. Entrepreneurship is critical and relevant in the study of disruptive innovation as it involves both competence enhancing and destroying elements that often leads to disruptive phenomena, by means of new opportunity discovery and exploitation (Shane, 2000), new market creation, new logic (Sarasvathy, 2001, 2008), and new resource deployment. Despite the potential contribution of entrepreneurship-related research streams to the study and practice of innovation, few researchers have attempted to cross-fertilize the two disciplines to advance theory and practice of creating and managing disruptive innovation. We integrate the two research streams to answer an important question: what conditions and causal mechanisms influence disruptive innovation and therefore how can the disruptive process be managed?

This contribution posits that disruptive innovation is an entrepreneurial process that consists of multiple entrepreneurial dimensions at the cognition, action and system level. The process can be viewed as an holistic entrepreneurial phenomenon: an outcome of the co-evolution between firms, artifacts they create, and entrepreneurial consumers. Our approach to re-conceptualizing disruptive innovation builds on the latest research in entrepreneurship including the evolutionary views of entrepreneurship, effectuation, lead-user innovation, collective intelligence, and opportunity tournament.

This article proceeds with a critical review of the existing literature on disruptive innovation and areas which have not received adequate attention in current research. This is followed by a reconceptualization of disruptive innovation. We then develop a theoretical framework and advance a set of propositions that explains the conditions and causal mechanisms of disruptive innovation from an entrepreneurship lens. Our framework offers managerial and policy guidance for general managers to create and cope with disruptive innovation. We conclude with avenues for future research and discuss implications for managers.

\section{DISRUPTIVE INNOVATION: A THEORETICAL REVIEW}

The term "disruptive innovation" (see Christensen 1993, 1997, 2006) refers to a new technology that has both lower cost and performance in relation to existing dominant design, and takes on a different trajectory from mainstream technologies in the market. The key features of disruptive innovation can 
be reduced to (i) affordability, (ii) simplicity, and consequently, (iii) unexpected replacement of large incumbents by new, smaller entrants. Classic examples include the replacement of: bigger by smaller disk drives, integrated steel mills by minimills, cassette tapes by compact disks and later by the MP3, silver halide film by digital cameras, and many others. To mention a few popular brand names, examples include the replacement of Xerox's high-end copier by low end, less expensive designs by Ricoh and Canon (Wright et al., 2004) as well as Digital Equipment Corporation's personal computers by makers of microprocessor based computers, to the threat posed by Samsung to Sony in the digital electronics product category (Chang, 2008).

As research in this area evolves and new empirical evidence is discovered (see Danneels, 2004), the theory of disruptive innovation also evolves. Some scholars suggest and show evidence that disruptive innovation does not necessarily have to be inferior in quality and can also occur from top to bottom, aiming at high-end, less price sensitive customers (Utterback and Acee, 2005; Rao et al., 2006). Others suggest that prior research has loosely used the term 'disruption' and underlined the importance of making a conceptual distinction between product and business-model focused types of disruptive innovation (Markides, 2006). In a recent review of the state-of-the-art of research in disruptive innovation, Christensen (2006) highlighted the value of building normative theory of disruption, citing the work of Adner (2002). Nevertheless, research in this area is still pre-occupied with building descriptive theory through the development of better typologies and categorization and seeking of anomalies considered as disruptive innovation (Christensen, 2006). Importantly, there has been little research conducted on strategies that can guide CEOs and general managers to create disruptive innovation and/or to protect their businesses from being disrupted in the market. We believe that knowledge of and capability to create and cope with disruptive innovation is critical for corporate longevity, especially for firms operating in fast changing environment.

To better study disruptive innovation and given the diversity of research and definitions in this area, we believe that there is a need to modify Christensen's original definition of disruptive innovation into the following: a phenomenon in which a new product (including service, process, and business model) replaces existing dominant design with exceptional commercial success. We argue that disruptive innovation cannot be defined from the standpoint of technological success alone but should also include market/commercial success. This modified definition could reconcile conflicting definitions and focal points of prior research and bring a focus on the phenomenon where incumbents are replaced by 1) new product, 2) unexpected encroachment from the periphery (rather than the center) of the existing market, and 3) which results in the attainment of exceptional market/commercial success in addition to technological success.

Following from the research question posed in the preceding section, we conducted a systematic review of the literature to understand the how and why (i.e. drivers, conditions, causal mechanisms) 
that influence disruptive innovation. Because innovation is a loosely used term in many published articles, we limit the scope of our survey to peer-reviewed literature pertaining to disruptive innovation. To identify relevant disruptive innovation articles, we conducted a keyword search on ProQuest Business encompassing 1980 to 2011. Keywords included 'disruptive innovation', 'disruptive technologies', 'creative destruction', 'radical innovation', 'dominant design', and 'Christensen'. This resulted in 184 articles. However we realized that there are many articles that frame disruptive innovation only as a context and illustration or proposing a new methodology, or proposing a new framework, which are not of our interest (e.g. Currah, 2007 that focuses on 'Hollywood and the role of internet' rather than the how and why of disruptive innovation; or Reinhardt and Gurtner, 2011 that focuses on 'methods' of customer analysis to develop disruptive innovation; or Glazer, 2007 which is a conceptual rather than an empirical paper). We excluded these papers from our survey. Research published in edited books (except Christensen's books and Zeng and Williamson's book on China's disruptive cost innovation) and conference proceedings was excluded as not all of these are accessible and or peer-reviewed.

To ensure thorough coverage, we also conducted a manual review of journals that have editorial interest in (disruptive) innovation, for volumes 1980 to 2011, which include Journal of Product Innovation Management, R\&D Management, Technovation, Research Policy, International Journal of Innovation Management, Industrial and Corporate Change, and Technology Analysis \& Strategic Management. We also manually reviewed Strategic Management Journal, Academy of Management Review, Academy of Management Journal, Organization Science, Management Science, Administrative Science Quarterly, Academy of Management Perspective, Journal of Management Studies, Journal of Management, European Management Journal, Journal of General Management, Journal of Marketing, Marketing Science, Sloan Management Review, Harvard Business Review, and California Management Review. These are generally considered to be the leading peer reviewed journals that frequently publish articles related to innovation and or disruptive innovation.

From this additional survey, we excluded papers that are at the periphery of the domain of disruptive innovation and whose focus are not related to the how and why of disruptive innovation, such as principles in evaluating disruptive technologies (e.g. Bucher et al., 2003; Hall and Martin, 2005), different R\&D characteristics of disruptive innovation (e.g. Yu and Hang, 2011), or willingness to cannibalize sales/capabilities (e.g. Nijssen et al., 2005), or methods of scenario planning for disruptive technology (e.g. Ho and Chen, 2009).

Importantly, from the remaining 45 papers at hand, we then examined them using content analysis and through peer reviews identified 14 key papers that are highly relevant to our understanding of the how and why (i.e. conditions and causal mechanisms) of disruptive innovation, as shown in Table 1. At 
this final stage, we are left with 31 articles that are important as they reveal the trends in innovation which form part of our discussion in the next section.

Our analysis on the literature surveyed suggests that the key articles in the field contain elements that are strongly relevant to entrepreneurship. As shown in Table 1, the entrepreneurial elements include various constructs and research themes such as the trade-offs between effectuation versus causation to viewing and managing the market as well as managing resources and developing capabilities; the presence and influence of entrepreneurial customers in the market, the effect of entrepreneurship on firms' structure, the role of Entrepreneurial Orientation on performance, entrepreneurial dynamics via trial/error and sense making, the influence of prior knowledge on entrepreneurial discovery, and exploitation of cross-border entrepreneurial advantage. Therefore, there is a good reason to speculate that the entrepreneurship literature may offer contributions to advance the disruptive innovation research and offer valuable guidance to managers. However, as shown in the table, to-date the direct linkage between the two streams of research has been minimal.

\section{Table 1 goes about here}

Our analysis on the papers shown in Table 1 also suggests that there has been an emphasis on studying the disruptive phenomenon from either the supply (i.e. firms and the artifacts they create) or demand (i.e. customers and their behavior) perspective. This table suggests that the supply perspective tends to be more popular in the literature; however, research on the impact of entrepreneurial consumers (i.e. demand-side perspective) on disruptiveness is scarce. We also notice that few studies attempt to investigate the disruptive innovation phenomenon from both perspectives, i.e. how the supply (entrepreneurial firms and their artifacts) and demand (entrepreneurial customers) sides coevolve over time. We synthesize these and other important trends and gaps from our survey of the literature in the next section.

\section{POTENTIAL DIMENSIONS OF DISRUPTIVE INNOVATION}

Our literature survey highlights two important themes or dimensions pertaining to disruptive innovation which have not received the attention they deserve in the literature: 1) the role of entrepreneurial dynamics and 2) the shift of locus of intelligence and innovation. From this insight, we conducted another extensive survey of the entrepreneurship and innovation literatures using the same approach described in the preceding literature review section. Our focus was to better understand the latest trends and empirical findings that may help us in the conceptualization stage in the next section. The two dimensions are discussed next. 


\section{Entrepreneurial Elements of Disruption}

As a form of Schumpeterian "creative destruction", disruptive innovation falls squarely within the discourse and traditions of entrepreneurship research. Nevertheless, there is a paucity of research in this domain that adopts an entrepreneurial lens. There are at least three important elements from entrepreneurship research that are not well understood in the context of disruptive innovation: (i) the sources of opportunity, (ii) uncertainty in entrepreneurial action, and (iii) entrepreneurial logic. Each of them will be discussed below.

Disruptive innovation can be described as a form of entrepreneurial opportunity that is radical rather than incremental in nature (Shane and Venkataraman, 2000; Eckhardt and Shane, 2003). This applies to product, service, and business-model opportunities, and the definition that we adopt in this article. While current research in disruptive innovation has made a distinction between disruptive and sustaining innovation, an important question has been left unanswered: a question of where an opportunity comes from, i.e. sources of entrepreneurial opportunity. Do entrepreneurial opportunities related to disruptive innovation exist, independent of the perceptions of entrepreneurs and waiting to be discovered? Or, are these opportunities imagined, enacted, and then created by the actions of entrepreneurs? Or else, are they the result of problemistic search by entrepreneurs according to the behavioral theory of the firm? Are disruptive innovations easier generated internally or externally? These are important questions that entrepreneurship research often asks (see Kirzner, 1997; Shane, 2000; Alvarez and Barney, 2007; Shepherd et al., 2007).

Importantly, what kind of entrepreneurial opportunities leads to disruptive innovation? Does certain form of opportunities tend to lead to disruption than the others? Does it follow a truly revolutionary or evolutionary pattern? In other words, understanding the nature of opportunities is critical as it has important implications on the effectiveness of a wide variety of entrepreneurial actions in different contexts.

Any discussions on entrepreneurship may be incomplete without referring to one of its core concepts: uncertainty. Uncertainty is a key element of the theory of entrepreneurial action (McMullen and Shepherd, 2006). Entrepreneurship research makes a distinction between "risk", which is calculable and knowable, and "Knightian uncertainty" (or true uncertainty), which is incalculable and unknowable (Knight, 1921; Langlois and Cosgel, 1993; Miller, 2007). Questions arise as to what type of uncertainty is associated with disruptive innovation opportunity and how entrepreneurs, either incumbents or new entrants, perceive and deal with uncertainty. Understanding the nature of uncertainty is critical since each type requires different types of entrepreneurial action. Dealing with Knightian uncertainty using approaches that are more appropriate for risky situations may lead to unprecedented problems, and vice versa. 
The third element rarely mentioned in the current theory of disruptive innovation is decision-making logic: causal versus effectual, and how this links to the view of product and market existence (see Sarasvathy, 2001; Wiltbank et al., 2006). Christensen's (2006) statement - "maybe there is something about good management that sows the seeds of eventual failure" - could be a reflection of the limits of the logic-in-use that hampers large incumbents' ability to deal with uncertainty created by new, small entrants. Which logic to be used relates to the perception and understanding of the nature of uncertainty. However, little research has been done to study the interactions between these two business logics and their influence on disruptive innovation.

\section{Shift in the Locus of Innovation and Intelligence}

Recent shift in the locus of innovation has also received scant attention in the disruptive innovation literature. The theory of disruptive innovation has traditionally embraced the notion that wellestablished firms (i.e. incumbents) are the epicenter of knowledge and primary sources of innovation. This conventional view of innovation is based on the notion of centralized intelligence logic. Recent trends towards open (distributed) innovation (see Gassmann et al., 2010; Chesbrough, 2003; Christensen, Olesen, and Kjaer, 2005) or the notion of "collective intelligence", recognizes that the "wisdom of the crowds" (Surowiecki, 2005) is generally missing from the theory of disruptive innovation. The crowds refer to: (i) the firm as innovator, (ii) the consumer as lead-user innovator, and (iii) the innovative consumer (who adopts innovation following the lead-user innovator).

The least explained locus of disruptive innovation among these in the literature is the consumer as lead-user innovator, which is growing rapidly in the literature on innovation and technology management (Oliveira and Von Hippel, 2011; Von Hippel and Von Krogh, 2003; Von Hippel, 2005). These consumers are lead-users whose mind, behaviors, and actions are ahead of the market, possess certain advanced technological knowledge, and get involved in user-innovation communities for both pecuniary and non-pecuniary motives. Examples include individuals and their communities who experiment and develop new ideas leading to the rise of new industries and technologies such as mountain biking, kite surfing, surgical equipment, open source software, printed circuit CAD (computer-aided design), juvenile products, toys, etc. Simpler, cheaper, and more convenient products/services - characteristics of disruptive innovation - are often found in the innovations generated by user-innovators.

The fact that large firms increasingly co-innovate with smaller firms and innovative communities outside the firm boundary needs to be reconciled with the extant theory of disruptive innovation. Firms, such as 3M, IBM, Merck, Intel, Phillips, Lego, and Bang \& Olufsen, have capitalized on the innovation generated by external innovative entities and generated substantial revenues from this new approach in the past decade. Eli Lilly created Innocentive.com, a platform allowing seekers (i.e. firms) 
and solvers (i.e. lead-users or experts) of technological problems scattered around the world to converge. This platform ultimately helps large incumbents find effective technological solutions at a much lower cost. Linux, one of the most successful open source software, is potentially challenging Microsoft's Windows and Sun's Unix operating systems. In light of the open innovation trend (or threat), Sun Microsystems also began experimenting with open innovation through its Open Solaris platform in recent years.

The body of work on innovation tournament (see Terwiesch and Ulrich, 2009; Girotra et al., 2010) that demonstrates how firms, from large pharmaceutical to award-winning animation house, can create and select innovation opportunities from a large pool of external sources (i.e. the crowds) to find the best opportunities/ideas is a recent trend that is worth noting. While the best ideas may come as an accident or an art, the process of finding the lucky accidents can be better managed scientifically, and hence more effectively and efficiently by firms soliciting ideas from the crowds outside. This scientific approach to widening the variance of the quality of the opportunities/ideas is the key to discovering the lucky accidents. This underlines the growing recognition of the shift of the locus of innovation and intelligence from internal to external sources.

In the next section, we will weave the insights from the aforementioned discussions into our conceptual framework.

\section{DISRUPTIVE INNOVATION AS A CO-EVOLUTIONARY ENTREPRENEURIAL PROCESS: A THEORETICAL FRAMEWORK}

Drawing on the theory of entrepreneurial logic (Sarasvathy, 2001), the theory of entrepreneurial action (McMullen and Shepherd, 2006), as well as the definition of entrepreneurial dynamics (McKelvey, 2004), we first define entrepreneurship as the formation of new artifacts at the product and firm level that replaces old with new value through entrepreneurial action under conditions of uncertainty and change. The artifacts here refer to not-yet-in-existent products (including services and business models) which are extremely unique in their degree of novelty (e.g. the creation of electricity, internet) to radical improvement of already-in-existence products which are high in their degree of newness (e.g. the creation of no-frills airlines, online brokerage, digital cameras, small disk drives and MP3) that causes the replacement of incumbents by new entrants.

Disruptive innovation can be considered as a subset of entrepreneurial process where perennial conflict between opposing forces (i.e. the defenders versus challengers), logics, and trajectories occurs in the formation of new artifacts to replace old with new value. This perennial conflict is an underlying cause for what Schumpeter called "creative destruction" in the economy. 
In this section, we propose a new framework that explains the conditions and causal mechanism that drive disruptive innovation (see Figure 1). The framework integrates the effectuation theory of entrepreneurship, evolutionary entrepreneurship, lead-user innovation, and opportunity tournament literature. The framework proposes disruptive innovation as a co-evolutionary entrepreneurial process between firms, artifacts they create, and consumers. Each of these evolutionary forces is described below.

\section{Figure 1 goes about here}

\section{Business-Level Drivers}

\section{Effectual and Causal logic}

In the proposed framework, the clash between causal and effectual logic among market players is an important driver of disruptive innovation (Sarasvathy, 2001, 2008). Causation (i.e. causal logic) focuses on the predictable aspects of an uncertain future. It shares a similar concept with the rational decision-making model that is appropriate under conditions of low complexity and low time pressure (see Rahman and De Feis, 2009). Its underlying logic is: to the extent we can predict the future, we can control it. In this approach, firms conduct strategic planning and market research, develop formal business plans, perform competitive analysis, and so forth. Such formalization of business practices influence a firm's propensity to focus on the 'core', the largest size of the target market, i.e. the center of the bell curve of the diffusion of innovation (Rogers, 2003).

Effectuation (i.e. effectual logic) explains how artifacts (e.g. products, firms, markets) come to be rather than assuming their pre-existence. It assumes a set of means (who you are, what you know, and whom you know) as given and unalterable, and focuses on selection between possible effects that can be created with that set of means (Sarasvathy, 2001, 2003; Wiltbank et al., 2006). It advocates affordable loss rather than expected return, alliances rather than merely competition, exploiting contingencies rather than exploiting pre-existing knowledge, and controlling an unpredictable future rather than predicting an uncertain one. It rests on the logic: to the extent we can control the future, we do not need to predict it. It serves the 'periphery' rather than the core of the market, where flexibility, playfulness, experimentation, and mistakes are tolerated. This body of work has been developed by the group of researchers led by Sarasvathy under the name of "effectuation", which builds upon Herbert Simon's work on boundedly-rational decision making model (see also Rahman and De Feis, 2009).

Established firms - with their accumulated knowledge, resources, and networks in the market - are typical adopters of causal logic as these organizational slack provide an incentive to 'predict' the market as a way of dealing with uncertainty (Sarasvathy, 2008). The possession of these assets 
induces top management to predict the market, regardless of whether a market exists or not (Miller and Chen, 1996). Not only is this logic feasible in dealing with already-existing market for incumbents but it is also often a compulsory logic-in-use as the firms are held accountable by their external stakeholders such as investors and government. In other words, institutional-political forces compel incumbents to adopt such logic.

In contrast, start-ups and informal entrepreneurs (i.e. individuals and innovating communities) that do not operate within the framework of a formal, established organization, are the natural adopters of effectual logic since this is often the only feasible way of navigating the market in the face of liability of smallness (Aldrich and Auster, 1986) and newness (Stinchcombe, 1965).

Evidence from the literature suggests that both logics work within a certain boundary condition and are susceptible to different types of error. Over reliance on the core and largest size of the target market (from the inference of causation) can lead to myopia in the market (Gilbert, 2003; Zhou, Yim, and Tse, 2005) and cause Type 2 error, which is the error of failing to observe a difference when in truth there is one (thus indicating a test of poor sensitivity), and ultimately failure. Too much a focus on the periphery of the market (from the logic of effectuation) may lead to over-trust (Goel and Karri, 2006), inefficiency, and slower rate of growth than a firm's true potential. Depending on how a firm evolves and learns, there can be a transition period where a firm gradually shifts from effectual to causal logic as experience, resources, and market develop (Sarasvathy, 2008). This portrayal of the gradual shift from effectual to causal logic resonates with Schumpeter's description of innovative entrepreneurship (1939) in the early to mature stage of railway development in the United States. Evidence of both logics is also implied in the following quote from Christensen, Craig and Hart (2001: 87) on the renowned Sony Corporation:

Until the 1970s, Sony's product launch decisions were strongly guided by its chief executive officer, Akio Morita, who followed his intuition rather than conducting careful market research to unearth the potential new products (showing evidence of effectual logic). But as the company became huge and successful in the 1980s, it had to hone its good management practices in market research, planning, budgeting, and resource allocation (showing the evidence of using causal logic). These careful, rational processes, which are crucial to an established company's efficient operation, prevented one of history's successful 'serial disrupters' from succeeding at new market creation.

The over-reliance on causal logic is well illustrated in Christensen's example of the replacement of hard-drive manufacturer Seagate in the advent of 3.5 inch architecture. Apparently, Seagate's marketing department responded with extensive information indicating that the new product's market and margin were small. Consequently, the top executives at Seagate forego this opportunity (Reed and DiFillippi, 1990). 
How IBM/ AT\&T versus Nokia responded to the same type of opportunity is another interesting example. In the case of IBM, the limit of causal logic was evident when the firm hired a leading consulting firm to gauge the size of the emerging minicomputer market. The study showed nil opportunity for IBM. Five years later, minicomputers became a multi-billion dollar business (Gilbert, 2003). In the mid 1980s, AT\&T commissioned a leading consulting firm to conduct in-depth market research on the emerging cell phone market. The study concluded that this is a very small market and recommended AT\&T to pull out of the cell phone market. Apparently, further development of cell phone technology primarily by Nokia led to the development of cell phones with reliable coverage at reasonable price points, which later disrupted the land-line phones (Govindarajan and Kopalle, 2006). In both examples, causal logic obviously confined the behavior and focus of the firms and their top executives to the core of the market, leading them to make Type 2 error.

Our basic premise is that each logic adopted will influence many aspects of the firm, including how resources are used, which strategic direction is taken, which capabilities are developed, which markets are targeted, when to enter new markets and launch new innovations, how the organization and its operations are structured, and such forth. Effectuation and causation thus serve as the operating philosophy of how a firm interacts with its environment.

Effectuation as a practice is in line with the philosophy underpinning design-driven innovation, an emerging body of work by Verganti and colleagues (see, Verganti, 2009; Dell'Era and Verganti 2009, 2010), that emphasizes the importance of the designers (as individuals and firms) who radically innovate what things mean. The design driven innovation does not take into account of what consumers currently want or tell what they want (i.e. does not adopt causation approach), but rather using the stimuli and sensing what extant products means to consumers and making proposals to create or alter the meanings about possible new products that people have not realized they would need or that they were eventually just waiting for. When the product meanings are radically changed or re-interpreted, the design of a product may radically change too, which may lead to products with disruptive innovation characteristics. The process of proposing breakthrough meanings relies on external interpreters (including firms, researchers, designers, and artists) who show similar interests in the same problem: to understand the evolution of socio-cultural models and technologies, and propose new visions and meanings. This culturally-driven approach to innovating has its roots in the studies and practices of design and originates from the successful innovation practices in Italian design-intensive manufacturers such as Alessi, Artemide, and Kartell. We believe that while design driven innovation does not absolutely guarantees the creation of (low-cost) disruptive innovation, it clearly enhances the chances of generating disruptive products in the market. Apple's phenomenal success with iPhone 4 can be, partly, attributed to the use of design-centric innovation that relies on effectuation strategy and whereby many technical and cultural interpreters reside within the firm. 
We argue that the adoption of the effectual or causal logic may be influenced by the age and size of the firm. As a small, new entrant grows larger, there is a natural tendency for its top management to switch towards more on causal logic; however, start-ups enter the market and usually rely more on effectual logic. This transition of logic-in-use along firm's growth lays the foundation for the next clash of market logics and consequently, the next disruptive innovation. The process repeats itself in the subsequent periods. Arguably, firms that embrace contradictions (i.e. maintaining a balance between effectual and causal logic) will be better adapted to possible disruptive threats. We therefore conclude:

Proposition 1a:

Disruptive innovation phenomenon is driven by the clash between effectual and causal logics in the market.

Proposition 1b:

Incumbents are more likely to be the adopters of causal logic than new entrants. Consequently, incumbents are more likely to overlook potential disruptive threats that encroach the market from the periphery.

Proposition 1c:

Disruptive innovators are more likely to be the adopters of effectual rather than causal logic.

Proposition 1d:

Incumbents that adopt both effectual and causal logics are less likely to be replaced by competitors and new entrants.

\section{Entrepreneurial Luck}

Serendipity, luck, or chance is ubiquitous in the history of entrepreneurship. The success of Honda in the US motorcycle market was accidental (Mintzberg et al., 1996). So is the emergence and success of Linux. The role of luck has been acknowledged by scholars in strategic management (Barney, 1986; Reed and DiFillippi, 1990), evolutionary economics (Nelson and Winter, 1982; Nelson, 1991), and organization ecology (Hannan and Freeman, 1977), etc. More recent evidence of luck can be found among 'accidental' entrepreneurs/innovators in the domain of lead-user innovation in which individuals happen upon an idea through their own use, then share it with others and, finally commercialize it across various industries (see Christensen, Olesen, and Kjaer, 2005; Shah and Tripsas, 2007).

The entrepreneurship literature makes a clear distinction between uncertainty and risk (Knight, 1921; Wiltbank et al., 2006). Luck and chance exist due to the presence of Knightian uncertainty. It is akin to calculating the probability of drawing a blue ball from a jar containing unknown number of colors 
of balls and unknown numbers of balls. Thus, it is unpredictable and unknowable. This is obviously different from risk that is calculable and predictable.

Despite the above description of luck, our framework of disruptive innovation does not rest upon the notion of pure chance. Rather, we view luck as a situation which favors the prepared and capable minds. Luck can strike only firms who happen to be prepared to seize it when an opportunity presents itself. In our theoretical framework, disruptive innovation is a phenomenon characterized by Knightian uncertainty whose occurrence cannot be predicted in advance by incumbents and new entrants alike. Potential trajectories of the market consist of an unknown number of combinations and permutations, many of which cannot be predicted since they require the recombination with yet to be known knowledge/invention prior to the emergence of the next invention (Ethiraj and Levinthal, 2004). Therefore, the technological search space may be infinite. By default, this creates Knightian uncertainty.

At the firm level, interdependent architectures (Ulrich, 1995) often cause a situation where something depends on something else. This is another source of Knightian uncertainty. For instance, in early mainframe computers, the logic of circuitry could not be designed until the operating system was designed; the operating system could not be designed until the core memory was designed; and, the core memory could not be designed till the logic of circuitry had been designed (Christensen, Verlinden, and Westerman, 2002: 962). This is similar to the interlinkages of systems and subsystems that are highly inter-related (Ethiraj and Levinthal, 2004). At the other level, customer preference for new products based on the potential technological trajectories is also often unknowable before the market for the products is clearly defined and develops; but, this can be known after it happens. The high mortality rate of start-ups has something to say about the role of chance as much as capability in replacing resource-rich, highly experienced, and highly networked incumbents. Formally,

\section{Proposition 1e:}

Disruptive opportunity is ex ante unknown and unknowable to both existing incumbents and new entrants.

\section{Proposition 1f:}

Despite the appearance of luck or pure chance, specialist firms that have high degree of expertise and unique set of assets are more likely to become disruptive innovators than other firms. 


\section{Product-Level Drivers}

\section{Evolutionary product morphology: adaptation and exaptation}

The evolutionary view, owing its roots in the evolutionary theory of natural selection, is a growing theme of research in entrepreneurship and is relevant to explain disruptive innovation. The evolutionary process can be categorized into (i) historical genesis: features built by natural selection for their present role, and (ii) current utility: features now enhancing fitness no matter how they arose (Gould and Vrba, 1982; Gould, 2002).

The former is associated with the primary product of the evolutionary process (or naturally selected features (adaptations)). That is, markets and firms create selective pressures for the adaptation of products in the direction of demand-side factors, such as customer needs, and supply-side factors, such as production efficiencies. Products that are selected in the process will be retained, diffused, and even imitated (Nelson and Winter, 1982).

The latter is the by-product of the evolutionary process (i.e. exaptation) and residue of noise (i.e. spandrels) (Lewin, 1982; Buss et al., 1998). For example, the feathers of birds are believed to be evolved mechanisms for thermal regulation; however, over time the feathers appeared to have been co-opted for a different function - flight (Lewin, 1982). These by-products emerge because selection mechanisms do not always guarantee optimal design (Buss et al., 1998).

Exaptation, a feature co-opted for its present role for new purposes but not an adaptation for its current function, is an important concept in the emerging paradigm of evolutionary entrepreneurship (Dew et al., 2004). The history of entrepreneurship has revealed evidence of exaptation that causes disruption in the market (see Dew et al., 2004; Dew et al., 2008). For example, the CD-ROM was designed originally for digital-to-optical recording and playback system but was co-opted later for data storage. Edison's phonograph, designed originally as a dictating machine, was co-opted as jukebox. These two inventions formed the basis of the music industry. Other examples include the cooptation of laser, agricultural tractors and many others. Viagra's success came from exaptation of drugs for the treatment of heart problems into male-enhancement substance. These real world examples suggest that exaptation and its residue can be the potential sources of disruptive opportunities. Furthermore, they might generate higher disruptive potential than the conventional historical genesis (i.e. primary product of technological evolution).

The competing forces between adaptation (i.e. Darwinian natural selection) and exaptation (i.e. the by-product of unintentional natural selection) create instabilities and disequilibria that result in Knightian uncertainty in the trajectory of the market. We thus suggest that the clash between the two main morphologies of evolutionary processes is an important causal mechanism that leads to disruptive innovation. Formally, 


\section{Proposition 2a:}

The clash between adaptation and exaptation forces in product forms is an important driver of disruptive innovation.

More specifically, we propose that:

Proposition 2b:

Exaptation process is more effective in generating disruptive innovation than adaptation process.

\section{Consumer-Level Drivers}

\section{User-innovators and innovative consumers}

The lead-user literature suggests that lead users and their communities are important sources of innovation opportunities (Von Hippel, 1986, 2005; Schreier and Prügl, 2008). Lead users can be individuals who act as entrepreneurial innovators informally (see Chandra and Coviello, 2010) as well as organizations/firms as a formal entity. Together with consumers who take risks, be proactive and innovative in their mindsets in adopting new products (i.e. innovative consumers), they co-evolve with firms in determining technological and market trajectories. These entities are the co-designers of the evolutionary product morphology (discussed earlier) and are important mechanisms of disruption.

'Sticky' information often impedes existing incumbents from knowing precisely what their consumers want particularly for novel artifacts (Polanyi, 1958; Von Hippel, 1998). Lead-user innovators, their innovating communities, and innovative consumers possess distinct advantages in understanding the tacit and continuously evolving customer preference and therefore, can influence the preference formations (Carpenter and Nakamoto, 1994) and trajectories of technologies that have the potential for causing disruption but are not in the radar of incumbents.

The philosophy of lead-user innovation shares commonality with the concept "collective intelligence" (Stinchcombe, 1965; Sulis, 1997; Bonabeau and Dorigo, 1999). Prior studies show that collective intelligence offers advantages not only for man-made organizations but also for animal organizations. These include the power of collective mind in organizing aircraft carrier flight decks (Weick, 1979; Weick and Roberts, 1993) and 'creative collectives' in problem solving at work (Hargadon and Bechky, 2006). In a study of social animal behavior, evidence shows that systems adopting collective intelligence tend to be more efficient in generating solutions to problems (Bonabeau et al., 2000).

A system that adopts collective intelligence may face fewer threats to disruptive innovation since new innovative ideas are involved and co-opted in the co-innovation activities and gain economic benefits from being a part of the creative collectives. The practice of design-driven innovation eventually 
relies on collective intelligence logic, in which the design intensive firms solicit external interpreters (e.g. firms, researchers, designers, developers, artists, etc) who can propose new meanings to a product. For instance, Apple's phenomenal success with iPhone can be, partly, attributed to the networks of external applications (or "apps") developers who create an ecosystem of apps (see Sorrel, 2010) that offers a wide degree of product assortments for Apple that cater to the heterogeneity of user needs. These external developers work together as virtual teams among each other (Ratcheva, 2008) are critical to Apple's technological networks to-date. Google's strengths is well attributed to its systematic search and acquisition of ideas and innovation opportunities from external, individual IT programmers around the world. These two firms have been able to protect themselves from the threats of disruptive innovation by embracing the external creative collectives in their business model.

The body of work in lead-user innovation reported in the literature contains an extensive array of evidence showing that lead-users only tend to generate incremental innovation (e.g. the case of $3 \mathrm{M}$ innovation ${ }^{\dagger}$, see Lillien et al., 2002; for banking services, see Oliveira and Von Hippel, 2011), or creating new niche markets from ground up that do not disrupt any existing markets/technologies (e.g. mountain bike, Lüthje et al., 2005; kite surfing, see Von Hippel, 2005). More recently, the popular press reported that user-based design will result in average products, that might satisfy users, but will not delight them (see Denning, 2011). But is this really the case? While the evidence seems to be convincing, we argue that there has been misrepresentation in terms how the lead user was defined, and how the lead user studies were conducted and reported. User innovator often turns into user entrepreneur (see Chandra and Coviello, 2010; Shah and Tripsas, 2007), and later create new venture and become full-time entrepreneur as soon as they recognize the commercial attractiveness of the innovation. The entire body of lead-user innovation research focuses on individuals and the communities of people who are currently classified as lead users. Those who are previously a lead user in their life, and then eventually created/discovered blockbuster opportunity and disrupted the marketplace are missing in the peer-reviewed journals and popular press. Moreover, the opportunity development process, including those for disruptive innovation, does not happen overnight (see Chandra, Styles and Wilkinson, 2011), as it can take years, along the users or firm's life cycle. By the time the opportunity becomes truly disruptive, the lead users may have turned into a full time entrepreneurs operating under a formal organization. Thus, it appears that lead user innovations are never really disruptive and lead users are not disruptive innovators.

Borrowing the idea from user innovation/entrepreneurship research (see Chandra and Coviello, 2010 and Shah and Tripsas, 2007), we could define Mark Zuckerberg (the founder of Facebook), Sergey Brin and Larry Page (the founders of Google) and Pierre Omidyar (the founder of eBay) as lead users

\footnotetext{
${ }^{\dagger}$ Although Lead User idea generation in 3M generates more than eight times higher than forecast sales for average contemporaneously 'traditional' product, it is only generating \$146 million after five years. We do not consider this to be an exceptional commercial success.
} 
in their own respective fields who create disruptive innovations with both exceptional technological and commercial success (i.e. the lead user techies in social networking site, search engine, and online auction system, respectively). In other words, the definitional and sampling issues obscure the performance outcome of lead user innovation.

We argue that lead user innovation does not absolutely lead to either incremental or disruptive innovation. This depends on whether the lead user innovation contains so-called competence enhancing or competence destroying ${ }^{\ddagger}$ characteristics to the focal firm and other firms (see Gatignon et al., 2002). Lead user innovations that contain competence destroying characteristic are more likely to transform into disruptive innovation, while those that contain competence enhancing properties are more likely to transform into incremental innovation. From this lens, one could argue that Google creates a competence destroying innovation in the market - by creating powerful algorithms for making effective search on the internet, which wipes out the majority of the predecessor search engines. So is the case with Facebook's competence destroying innovation that ultimately eliminates most of the predecessor social networking sites for the general public.

Therefore, our framework considers the role of lead user innovation and the characteristics of the innovation (competence enhancing vs. destroying) as important influencing factors that lead to disruptive innovation. This offers strategies for general managers to ensure corporate longevity.

The above arguments lead to our next propositions:

Proposition 3a:

Lead user innovation that contains competence destroying characteristics is an important driver of disruptive innovation.

Proposition 3b: Firms that embrace collective intelligence in the innovation process, including lead user innovation that contains competence destroying characteristics, are more likely to create disruptive innovation in the market.

\section{Firm, Consumer, and Product Level Drivers}

\section{Opportunity Tournament}

In the preceding section, we highlighted the role of Knightian uncertainty (true uncertainty) and luck in the process of disruptive innovation. Recent research on innovation tournaments (see Terwiesch and Ulrich, 2009; Terwiesch and Xu, 2008; Kornish and Ulrich, forthcoming) demonstrate why and how firms can engineer the innovation process to find the best ideas out of the hundreds or thousands

\footnotetext{
* Competence enhancing innovation reinforces and build upon existing competencies, skills and know-how; while competence destroying innovation obsolesces and overturns existing competencies, skills and know-how (see Gatignon et al., 2002, p.1107)
} 
of ideas submitted by individual contestants. What innovation contest does is that it generates a wide variance of new ideas and use judges from the target market to assess the viability of each idea. In other words, the contest allows the firm to enhance their 'luck' or increase their probability of finding the next disruptive innovation opportunity more effectively and efficiently.

We use the term Opportunity Tournament here (rather than innovation tournament/contest) to encompass a wider range of opportunities because ideas themselves may not necessarily be tangible innovation themselves, some or many still require further refinement before they become disruptive opportunity. Research by Ulrich and colleagues has focused on the 'ideation and selection stage' as being critical in the innovation tournament. From an entrepreneurial lens, 'disruptive' opportunities often require further development before they can be selected and turned into exceptional market and commercial success. Hence, in keeping with the entrepreneurial theme in this conceptual framework, we label the process as opportunity tournaments.

Opportunity tournaments have been used by various large organizations, from Deloite Innovation Quest, American Idol, InnoCentive, QVC product road show, to DARPA Grand Challenge for autonomous robot vehicles, to survive and thrive in the market. It helps the firm to create more chances of generating disruptive opportunities to stay as market leader while at the same time protecting themselves from being disrupted by competitors/new entrants who commercialize the disruptive opportunities in the market. While academic research in this domain has only begun to spring, firms have taken an earlier plunge into the opportunity tournament and generated blockbuster opportunity and commercial success.

This leads to our final proposition:

Proposition 4: Firms that embrace opportunity tournaments in their innovation process are more likely to generate disruptive innovation.

To illustrate the framework advanced in this paper, we draw on one of the most exciting yet on-going battles in the mini computing device market: the first netbook versus iPad, and next, iPad versus Chromebooks. ASUSTek pioneered the netbook market with Eee PC in late 2007, aiming at users who require a light weight and a relatively low cost second computing device. Other major players in the computer industry including Acer, HP, and Dell jumped into the market by developing their Eee PC-like netbooks in the twinkling of an eye. In April 2010, Apple entered the second computing device market by launching iPad. Apple embraced "who I am, what I know, whom I know," principles from effectuation strategy, i.e. drawing on existing core competences and resources in iPod and iPhone, and transformed them into a line of tablet computers. The outcome of the effectuation strategy was clear: iPad consequently drained rivals' (e.g. Acer, Asus) resources from the netbook market and ate up a significant portion of the netbook market (Guardian 11/04/2011). Before too long, 
Acer and Asus retaliated by analyzing iPad's trajectory and ended up copying iPad's features, a strategic choice infused with "causation" strategy. But the situation did not look any brighter for Acer and Asus. Before too long, Google came into the scene. In May 2011, Google relies on effectual logic (by leveraging "who I am, what I know, whom I know") drawing on existing core competence and resources in its web-based computing including cloud-based computing and launched Chromebooks, a product which does not really require the hardware and software as commonly found in iPad and notebooks (BBC News 11/05/2011). Google went further by 'internalizing' external user innovators and communities. Many of the best user innovators in web-based computing are scouted and hired to work for Google and given the freedom and resources to work as if the hires were their own entrepreneurs. Hence, Google has been practicing "opportunity tournaments" consciously or/and unconsciously. The entire suite of strategies mentioned helps Google in launching disruptive innovation in the market and reduces the chances for Google to be disrupted by new entrants.

\section{CONCLUSIONS}

This article advances our understanding of disruptive innovation and underlines the relevance and potential contribution of entrepreneurship research to the disruptive innovation research. It integrates recent developments in the theories of effectuation, evolutionary entrepreneurship, lead-users, collective intelligence, and opportunity tournament, and reconceptualizes disruptive innovation as a co-evolutionary entrepreneurial process at the firm, product, and consumer level. It offers a theoretical framework of disruptive innovation and advances a set of testable propositions. The proposed framework explains conditions and mechanism that enhance the likelihood of an entity to create disruptive innovation, and to protect itself from being disrupted by start-ups/competitors.

The role of decision-making logic (effectual versus causal) and evolutionary morphology (exaptation versus adaptation) are critical drivers of disruptive innovation since they influence firms' mindsets, ways of doing things, and strategies. These recent developments have been confined to the entrepreneurship research streams. Little efforts have been made to study the impact of these business logics and evolutionary forces on disruptive innovation. The clash between the logics (effectuation vs. causation) and evolutionary morphology (exaptation vs. adaptation) is a critical condition that drives disruptive innovation. We suspect that disruptive opportunity may be better created by 'controlling' uncertain future through effectuation strategy (where Knightian uncertainty is assumed) than 'predicting' the uncertainty via causation strategy (where risk is assumed). Importantly, exaptation can be a much more influential driver to generate potential sources of disruptive opportunity than adaptation. Exaptation generates variance in the quality of innovation and hence enhancing the chances of creating 'outliers' that may turn into exceptional technological and market/commercial success. 
Lead-user innovation and collective intelligence literature can be fruitfully integrated into the research in disruptive innovation. Lead-users have been generally accepted as sources of incremental innovation. We argue that this characterization occurs as a result of misrepresentation of lead users, particularly on the way that lead users are defined and ignorance on the role of time in opportunity development. A number of world-class disruptive innovations in the online market (e.g. FaceBook, Google, eBay) were created by lead users (e.g. Zuckerberg; Brin and Page; and Omidyar, respectively) but these have been missing in the picture because lead users eventually evolve and transform into formal entrepreneurs and their organizations grow into world's largest companies. Critically, lead user innovation does not absolutely or simply lead to incremental or disruptive innovation. We argue that this depends on whether the lead users generate competence-destroying, which is likely to create disruptive innovation; or competence-enhancing innovations, which is likely to turn into incremental innovation.

Opportunity tournament is a more recent strategy that has shown to enhance firm's innovation performance and a critical driver of disruptive innovation. This approach has turned innovation from largely an uncontrollable activity or even an art into a scientific process of creating and selecting the most promising opportunities. Its strength lies in the generation of a wide variance of quality of innovation opportunities, and hence the higher chances of discovering the outliers or highly disruptive innovation with exceptional commercial opportunities. Since not all disruptive opportunities are born overnight (e.g. Google's search engine opportunity took some time to develop and refine before it becomes disruptive), the role of nurturing and cultivation of the initial disruptive opportunity cannot be ignored.

We believe that disruptive innovation may be better studied and understood from an holistic entrepreneurial lens, by looking at the interactions of multi-level factors (i.e. firm, product, and consumer). In so doing, we demonstrate that entrepreneurial perspective is a fruitful avenue of enquiry that will help advance knowledge in disruptive innovation.

Avenues for future research are multi-fold. First, future research may be undertaken by empirically examining the propositions advanced in the paper. Large scale quantitative studies are well suited to test and explore the propositions, such as Gatignon et al. (2002). These may include constructs that measure the presence or absence of effectual logic and action vs. causation for both disruptive and incremental innovators; assessment of CEOs and general managers' view of the nature of uncertainty surrounding disruptive innovation in their respective industry; examination of exaptation vs. adaptation forces in the industry at the product-level of analysis; measurement of the nature of innovations generated by lead users (competence destroying vs. enhancing); to measurement of the effectiveness of opportunity tournaments. 
Qualitative fieldwork research and structured content analysis are other viable approaches to test the framework proposed here (see Smith, Grimm, Gannon, and Chen, 1991; Chen and Hambrick, 1995. We suggest researchers to take into account the role of history of the firm and its personnel (i.e. lead user-ship) to make better sampling decisions when studying lead users, avoid the trap of misclassifying lead user innovation without an understanding of whether the innovation is competence destroying or enhancing, and ultimately make the valid generalization of their research. Since entrepreneurship is not a once-off activity but rather a continuous process along the life of an innovator/entrepreneur, it may be beneficial for studies of this nature to examine the dynamics of the disruptive opportunity development. This may help generate useful theory of the process of disruptive innovation

Computer simulation such as agent-based modeling is another useful methodology to test and explore the propositions advanced in this paper. This approach can be fruitfully used to test the outcome of the clash between agents that operate on causal versus effectual logic, the role of luck, as well as exaptation (e.g. Rivkin and Siggelkow, 2006). Results from this type of research can be further developed into formal models of disruptive innovation that can be used for both positive and normative purposes. For instance, dynamic system models may be developed to test the necessary and sufficient conditions for the emergence of disruptive innovation (e.g. Sterman et al., 2007). The formal modeling may offer new insights to the disruptive innovation literature that has mostly been developed through conventional empirical methods.

\section{IMPLICATIONS FOR MANAGERS}

The proposed framework advanced in this study offers a number of strategies for CEOs and general managers to create and cope with disruptive innovations particularly for those operating in rapidly changing environment.

We first highlighted the importance of effectuation and causation strategies. Disruptive innovation can be seen as the clash between existing technologies and firms with new technologies and firms who disrupt them and at a more extreme case, replaces them altogether. This clash begins with different business logic-in-use by the market players. If all firms adopt causation, then there would be fewer and less frequent upheavals in the market since every firm will focus on developing artifacts with characteristics that are already generally adopted/accepted as the status quo (near the centre of the bell curve). Imagine that all firms conduct surveys to predict the general market needs. If this really happens, then there will be no iPhone $4 \mathrm{~s}$ or Samsung Galaxy 2 today with features that are unimaginable by the standard mobile phone design. These phones have become the trendsetter smart phone with never-seen-before features. The fact that Apple relies heavily on effectuation (and a form 
of design-driven innovation, see Verganti, 2009; Dell'Era and Verganti, 2009, 2010) says a lot about the virtue of effectuation principles to enhance the chances of creating the next disruptive innovation.

One of the strategies to remain as disruptive innovators is to embrace effectuation principles along the firms life cycle, as what Apple, Google, and Facebook has been doing all along. The techie-leaders of these firms (e.g. Steve Jobs; Sergey Brin and Larry Page; and Mark Zuckerberg, respectively) dominate and influence the corporate culture such that the firms remain as the natural adopters of effectuation in their business practices and specifically in product design, despite that the firms have grown into large incumbents. The failures of many market leaders of the past could be seen as the result of myopic view of their CEOs and general managers of the potential threats from the periphery. As is the case with Sony Corporation, it fell into the trap of becoming overly driven by causation rather than effectuation strategy or a balance of both.

Predicting which artifacts or design will turn into the next disruptive innovation is not an easy task due to the presence of Knightian uncertainty (unknown and unknowable conditions) of plausible product/design features combinations and permutations. Apple or Google has no way of predicting which of their artifacts would disrupt the market ex-ante. But this can be known after it happens. Nevertheless, there are a number of strategies, in addition to effectuation/causation and the role of luck, that firms can adopt to create and cope with disruptive innovation, as discussed next.

From the product level, firms could explore ways to harness exaptation strategies. While the evolutionary entrepreneurship literature shows examples of truly accidental innovations, we believe the exaptation process can be engineered and embedded into a firm's innovation practices. Viagra's is a great lesson for CEOs and general managers on how products can be engineered using exaptation strategy into a blockbuster drug with exceptional medical and commercial success. The hand-motion sensor technology used in Nintendo Wii's remote control is a form of exaptation of using a design differently from its original purpose (i.e. originally used for television remote control), and led to enormous success of Wii which sold for more than 86 million units since its introduction in 2006 (see Takahashi, 2011). Using the exaptation strategy, firms can find new plausible ways of better use or new use or alternative use of their products and designs. Compared to the adaptation process in new product development, the exaptation process is more likely to increase the variance of the quality of the ideas and hence discovering outliers or extreme type of design and features, or selecting the best one(s). The clash between the product morphology (exaptation vs. adaptation) is crucial for the emergence of disruptive innovation.

Lead user innovation is an effective approach for leveraging outsiders and tap into their innovative ideas. Although the literature tends to report only the incremental innovation potential of lead users, we argue that the literature has overlooked the lead users such as the founders of Facebook, Google, and eBay who created disruptive innovation with phenomenal success. While there is no shortcut or 
quick therapy to generate highly disruptive lead user innovation, firms can work collaboratively with lead users to produce designs/artifacts/products that have the competence destroying characteristics (rather than competence enhancing ones). Since the disruptive opportunity is not a once-off event but involves opportunity development and further refinement processes, firms can guide and finance lead users to focus on opportunities that are competence-destroying.

Companies can leverage the communities of users of their products and learn to distinguish and reward top ideas and artifacts through company-based initiatives or even leveraging external online platforms that focus on this. A recent example is the Innocentive, an online platform developed by Eli Lilly, which allows a company to ask people in the communities of experts to solve a particular technological problem for a financial reward. Lego, for instance, cleverly leveraged the intelligence and resources of its communities of users (customers) to develop new robot games at much lower costs and faster development cycle (see Von Hippel, 2005).

Last but not least, firms can adopt opportunity tournaments to create and select exceptional opportunities. Research has demonstrated that the higher the variance of the quality of ideas/opportunities generated, the more likely that the exceptional or outlier ideas/opportunities will be generated. While discovering innovation has been thought of as an art or relies entirely on luck, the opportunity tournament strategy offers a scientific approach to finding the disruptive opportunities and turns them into reality. General managers can learn from American Idol and Pixar to find their next best blockbuster products. 


\section{REFERENCES}

Adner, R. (2002), 'When are technologies disruptive? A demand-based view of the emergence of competition', Strategic Management Journal, Vol. 23, No. 8, pp. 667-688.

Adner, R. and Zemsky, P. (2006), 'A demand-based perspective on sustainable competitive advantage', Strategic Management Journal, Vol. 27, No. 3, pp. 215-239.

Aldrich, H.E. and Auster, E.R.(1986), 'Even dwarfs started small: Liabilities of age and size and their strategic implications', In: Cummings, L.L., and Staws, B.M. (eds.), Research in Organizational Behavior, Greenwich: JAI Press, pp. 165-180.

Alvarez, S.A. and Barney, J.B.(2007), 'Discovery and creation: Alternative theories of entrepreneurial action', Strategic Entrepreneurship Journal Vol. 1, No. 1-2, pp. 11-26.

Anderson, P. and Tushman, M.L. (1990), 'Technological discontinuities and dominant designs: A cyclical model of technological change', Administrative Science Quarterly, Vol. 35, No. 4, pp. 604-633.

Barney, J.B. (1986), 'Strategic factor markets: Expectations, luck and business strategy', Management Science, Vol. 32, No. 10. pp. 1231-1241.

Bonabeau, E., Dorigo, M. and Theraulaz, G. (2000), 'Inspiration for optimization from social insect behavior', Nature, Vol. 406 (July), pp. 39-42.

Bonabeau, E., Dorigo, M. and Theraulaz, G. (1999), Swarm Intelligence: From Natural to Artificial Systems, Oxford: Oxford University Press.

Bucher, P., Birkenmeier, B., Brodbeck, H. and Escher, J. (2003), 'Management principles for evaluating and introducing disruptive technologies: The case of nanotechnology in Switzerland', R\&D Management, Vol. 33, No. 2, pp. 149-163.

Buss, D.M., Haselton, M.G., Shackelford, T.K., Bleske, A.L. and Wakefield, J.C. (1998), 'Adaptations, exaptations, and spandrels', American Psychologist, Vol. 53, pp. 533-548.

Carpenter, G.S. and Nakamoto, K. (1994), 'Reflections on consumer preference formation and pioneering advantage', Journal of Marketing Research, Vol. 31 (November), pp. 570-573.

Chandra, Y. and Coviello, N. (2010), 'Broadening the concept of international entrepreneurship: Consumers as international entrepreneurs', Journal of World Business, Vol. 45, No. 3, pp. 228 236.

Chandra, Y., Styles, C. and Wilkinson, I. (2011), 'An opportunity based view (OBV) of rapid internationalization', Journal of International Marketing (forthcoming). 
Chandy, R.K. and Tellis, G.J. (2000), 'The incumbent's curse? incumbency, size, and radical product innovation', Journal of Marketing, Vol. 64, No. 3, pp. 1-17.

Chen, M.-J. and Hambrick, D.C.(1995), 'Speed, stealth, and selective attack: How small firms differ from large firms in competitive behavior', Academy of Management Journal, Vol. 38, No. 2, pp. $453-482$.

Chang, S-J.(2008), Sony vs. Samsung: The Inside Story of the Electronics' Giants Battle for Global Supremacy, New Jersey: John Wiley.

Chesbrough, H. (2003), Open Innovation: The New Imperative for Creating and Profiting from Technology, Boston: Harvard Business School Publishing..

Christensen, C.M. (1993), 'The rigid disk drive industry: A history of commercial and technological turbulence', Business History Review, Vol. 67 (Winter), pp. 531-588.

Christensen, C.M. and Bower, J.L. (1996), 'Customer power, strategic investment, and the failure of leading firms', Strategic Management Journal, Vol. 17, No. 3, pp. 197-218.

Christensen, C.M. (1997), The Innovator's Dilemma: When New Technologies Cause Great Firms to Fail, Boston, MA: Harvard Business School Press.

Christensen, C.M., Suarez, F.F. and Utterback, J.M. (1998), 'Strategies for Survival in Fast-Changing Industries', Management Science, Vol. 44, No. 12 (2/2), pp. S207-S220.

Christensen, C. M., Craig, T. and Hart, S.(2001), 'The great disruption', Foreign Affairs, (March/April), pp. 80-95.

Christensen, C.M., Verlinden, M. and Westerman, G.(2002), ,Disruption, disintegration and the dissipation of differentiability', Industrial and Corporate Change, Vol. 11, No. 5, pp. 955-993.

Christensen, C.M. (2006), 'The ongoing process of building a theory of disruption', Journal of Product Innovation Management, Vol. 23, No. 1, pp. 39-55.

Christensen, J.F., Olesen, M.H. and Kjaer, J.S. (2005), 'The industrial dynamics of open innovation Evidence from the transformation of consumer electronics', Research Policy, Vol. 34, No. 10, pp. 1533-1549.

Collins, J. (2001), Good to Great: Why Some Companies Make the Leap and Others Don't, New York: HarperCollins Publisher.

Currah, A. (2007), 'Hollywood, the internet and the world: geography of disruptive innovation, Industry and Innovation, Vol. 14, No. 4, pp. 359-384. 
Danneels, E. (2004), 'Disruptive technology reconsidered: A critique and research agenda', Journal of Product Innovation Management, Vol. 21, pp. 246-258.

Dell'Era, C. and Verganti, R. (2009), 'Design-driven laboratories: Organization and strategy of laboratories specialized in the development of radical design-driven innovations', $R \& D$ Management, Vol. 39, No. 1, pp. 1-20.

Dell'Era, C. and Verganti, R. (2010), 'Collaborative strategies in design-intensive industries: Knowledge diversity and innovation', Long Range Planning, Vol. 43, No. 1, pp. 123 - 141.

Dew, N., Sarasvathy, S. D. and Venkataraman, S. (2004), 'The economic implications of exaptation', Journal of Evolutionary Economics, Vol. 14, pp. 69-84.

Dew, N., Read, S., Sarasvathy, S. D. and Wiltbank, R. (2008), 'Outlines of a behavioral theory of the entrepreneurial firm', Journal of Economic Behavior and Organization, Vol. 66, No. 1, pp. 37-59.

Dosi, G. (1982), 'Technological paradigms and technological trajectories', Research Policy, Vol. 11, No. 3, pp. 147-162.

Eckhardt, J.T. and Shane, S.A. (2003), 'Opportunities and entrepreneurship', Journal of Management, Vol. 29, No. 3, pp. 333-349.

Ethiraj, S.K. and Levinthal, D. (2004), 'Modularity and innovation in complex systems', Management Science, Vol. 50, No. 2, pp. 159-173.

Foster, R. and Kaplan, S. (2001), Creative Destruction: Why Companies that Are Built to Last Underperform the Market - and How to Successfully Transform Them, New York: Doubleday Publishing.

Gassmann, O., Enkel, E. and Chesbrough, H. (2010), 'The future of open innovation', $R \& D$ Management, Vol. 40, No. 3, pp. 213-221.

Gatignon, H., Tushman, M.L., Smith, W. and Anderson, P. (2002), A structural approach to assessing innovation: Construct development of innovation locus, type, and characteristics', Management Science, Vol. 48, No. 9, pp. 1103-1122.

Gilbert, C. (2003), 'The disruption opportunity', Sloan Management Review, Summer, pp. 27-32.

Girotra, K., Terwiesch, C. and Ulrich, K.T. Idea generation and the quality of the best idea, Management Science (forthcoming).

Glazer, R. (2007), 'Meta-technologies and innovation leadership: Why there maybe nothing new under the sun', California Management Review, Vol. 50, No. 1, pp. 120-143. 
Goel, S. and Karri, R. (2006), 'Entrepreneurs, effectual logic, and over trust', Entrepreneurship Theory and Practice, Vol. 30, No. 4, pp., 477-493.

Gould, S. J. and Vrba, E.S. (1982), 'Exaptation - a missing term in the science of form', Paleobiology, Vol. 8, pp. 4-15.

Gould, S.J. (2002), The Structure of Evolutionary Theory, Cambridge: Belknap Press.

Govindarajan, V. and Kopalle, P.K. (2006), 'The usefulness of measuring disruptiveness of innovations ex post in making ex ante predictions', Journal of Product Innovation Management, Vol. 23, No. 1, pp. 12-18.

Hall, J.K. and Martin, M.J.C. (2005), 'Disruptive technologies, stakeholders and the innovation valueadded chain: A framework for evaluating radical technology development', $R \& D$ Management, Vol. 35, No. 3, pp. 273-284.

Hannan, M.T. and Freeman, J. (1977), 'The population ecology of organizations', American Journal of Sociology, Vol. 82, No. 5, pp. 929-964.

Hargadon, A.B. and Bechky, B.A. (2006), 'When collections of creatives become creative collectives: A field study of problem solving at work', Organization Science, Vol. 17, No. 4, pp. 484-500.

Henderson, R.M. and Clark, K.B. (1990), 'Architectural innovation: The reconfiguration of existing product technologies and the failure of established firms', Administrative Science Quarterly, Vol. 35, No. 1, pp. 9-30.

Henderson, R. (2006), 'The innovator's dilemma as a problem of organizational competence', Journal of Product Innovation Management, Vol. 23, No. 1, pp. 5-11.

Ho, J.C. and Chen, J-S. (2009), 'Forecasting VoWLAN technology for the Taiwan mobile telecommunication industry', Technology Analysis \& Strategic Management, Vol. 21, No. 2, pp. $213-232$

Kirzner, I. M. (1997), 'Entrepreneurial discovery and the competitive market process: An Austrian approach', Journal of Economic Literature, Vol. 35 (March), pp. 60-85.

Kornish, L. J. and Ulrich, K. T. Opportunity spaces in innovation: Empirical analysis of large samples of ideas. Forthcoming in Management Science. Available at SSRN: http://ssrn.com/abstract=1503103

Knight, F.H. (1921), Risk, Uncertainty and Profit, New York: Houghton Mifflin. 
Langlois, R.N. and Cosgel, M.M. (1993), 'Frank Knight on risk, uncertainty, and the firm: A new interpretation', Economic Inquiry, Vol. 31, No. 3, pp. 456-465.

Lewin, R. (1982), 'Adaptation can be a problem for evolutionists', Paleobiology, Vol. 8, No. 4, pp. 1212-1213.

Lillien, G.L., Morrison, P.D., Searls, K., Sonnack, M. and Von Hippel, E. (2002), 'Performances assessment of the lead user idea-generation for new product development', Management Science, Vol. 48, No. 8, pp. 1042-1059.

Lüthje, C., Herstatt, C. and von Hippel, E. (2005), 'User-innovators and "local" information: The case of mountain biking', Research Policy, Vol. 34, No. 6, pp. 951-965.

Markides, C. (2006), 'Disruptive innovation: In need of better theory', Journal of Product Innovation Management, Vol. 23, No. 1, pp. 19-25.

McKelvey, B. (2004), 'Toward a complexity science of entrepreneurship', Journal of Business Venturing, Vol. 19, No. 3, pp. 313-341.

McMullen, J.S. and Shepherd, D.A. (2006), 'Entrepreneurial action and the role of uncertainty in the theory of the entrepreneur', Academy of Management Review, Vol. 31, No. 1, pp. 132-152.

Miller, D. and Chen, M-J. (1996), 'The simplicity of competitive repertoires: An empirical analysis', Strategic Management Journal, Vol. 17, No. 6, pp. 419-439.

Miller, K.D. (2007), 'Risk and rationality in entrepreneurial processes', Strategic Entrepreneurship Journal, Vol. 1, No. 1-2, pp. 57-74.

Mintzberg, H., Pascale, R.T., Goold, M. and Rumelt, R.P. (1996), 'The “Honda Effect" revisited', California Management Review, Vol. 38, pp. 78-91.

Nelson, R.R. and Winter, S. (1982), An Evolutionary Theory of Economic Behavior, Cambridge: Harvard University Press.

Nelson, R.R. (1991), Why do firms differ, and how does it matter?, Strategic Management Journal Vol. 12, (Special Issue: Fundamental Research Issues in Strategy and Economics), pp. 61-74.

Nijssen, E.J., Hillebrand, B. and Vermeulen, P.A.M. (2005), 'Unraveling willingness to cannibalize: A closer look at the barrier to radical innovation', Technovation, Vol. 25, No. 12, pp. 1400-1409.

Oliveira, P. and Von Hippel, E. (2011), 'Users as service innovators: The case of banking services', Research Policy, Vol. 40, No. 6, pp. 806-818. 
Polanyi, M. (1958), Personal Knowledge: Towards a Post-Critical Philosophy', Chicago: University of Chicago Press.

Rahman, N. and De Feis, G.L. (2009), 'Strategic decision making: Models and methods in the face of complexity and time pressure', Journal of General Management, Vol. 35, No. 2, pp. 43-60.

Ratcheva, V. (2008), 'The knowledge advantage of virtual teams - processes supporting knowledge synergy', Journal of General Management, Vol. 33, No. 3, pp. 53-67.

Rao, B., Angelov, B. and Nov, O. (2006), 'Fusion disruptive technologies: Lessons from the skype case', European Management Journal, Vol. 24, No. 2-3, pp. 174-188.

Reed R. and DiFillippi, R. (1990), 'Causal ambiguity, barriers to imitation, and sustainable competitive advantage', Academy of Management Review, Vol. 15, No. 1, pp. 88-102.

Reinhardt, R. and Gurtner, S. (2011), 'Enabling disruptive innovations through the use of customer analysis methods', Review of Managerial Science, Vol. 5, No. 4, pp. 291-307.

Rivkin, J.W. and Siggelkow, N. (2006), 'Organizing to strategize in the face of interactions: Preventing premature lock-in', Long Range Planning, Vol. 39, No. 6, pp. 591-614.

Rogers, E. M. (2003), Diffusion of Innovations (5th Ed.). New York: Free Press.

Sarasvathy, S.D. (2001), 'Causation and effectuation: Toward a theoretical shift from economic inevitability to entrepreneurial contingency', Academy of Management Review, Vol. 26, No. 2, pp. 243-263.

Sarasvathy, S.D. (2003), 'Entrepreneurship as a science of the artificial', Journal of Economic Psychology, Vol. 24, No. 2, pp. 203-220.

Sarasvathy, S.D. (2008), Effectuation: Elements of Entrepreneurial Expertise, Cheltenham: Edward Elgar.

Schreier, M. and Prügl, R. (2008), Extending lead-user theory: Antecedents and consequences of consumers' lead userness', Journal of Product Innovation Management, Vol. 25, No. 4, pp. 331346.

Schumpeter, J.A. (1934a), The Theory of Economic Development, Cambridge: Harvard University Press.

Schumpeter, J.A. (1934b), Change and the Entrepreneur, Cambridge: Harvard University Press.

Schumpeter, J.A. (1939), Business Cycles: A Theoretical, Historical, and Statistical Analysis of the Capitalist Process, Vol 2. New York \& London: McGraw-Hill. 
Shah, S.K. and Tripsas, M. (2007), 'The accidental entrepreneur: The emergent and collective process of user entrepreneurship', Strategic Entrepreneurship Journal, Vol. 1, No. 1-2, pp. 123-140.

Shane, S. (2000), 'Prior knowledge and the discovery of entrepreneurial opportunities', Organization Science, Vol. 11, No. 4, pp. 448-470.

Shane, S. and Venkataraman, S. (2000), 'The promise of entrepreneurship as a field of research', Academy of Management Review, Vol. 25, No. 1, pp. 217-226.

Shepherd, D.A., McMullen, J.S. and Jennings, P.D. (2007), 'The formation of opportunity beliefs: Overcoming ignorance and reducing doubt', Strategic Entrepreneurship Journal, Vol. 1, No. 1-2, pp. 75-95.

Smith, K.G., Grimm C.M., Gannon M.J. and Chen, M.-J. (1991), 'Organizational information processing, competitive responses and performance in the U.S. domestic airline industry', Academy of Management Journal, Vol. 34, No. 1, pp. 60-85.

Sterman, J.D., Henderson, R., Beinhocker, E. and Newman, L. (2007), 'Getting big too fast: Strategic dynamics with increasing returns and bounded rationality', Management Science Vol. 53, No. 4, pp. 683-696.

Stinchcombe, A.L. (1965), 'Organizations and social structure', In: March, J.G. (Ed.), Handbook of Organizations, Chicago: Rand McNally, pp. 142-193.

Sulis, W. (1997), 'Fundamental concepts of collective intelligence', Nonlinear Dynamics, Psychology and Life Sciences Vol. 1, No. 1, pp. 35-53.

Surowiecki, J. (2005), The Wisdom of Crowds, New York: Anchor Books.

Terwiesch, C. and Ulrich, K. (2009), Innovation Tournaments, Boston, MA: Harvard Business Press.

Terwiesch, C. and Xu, Y. (2008), 'Innovation contests, open innovation, and multi-agent problem solving', Management Science, Vol. 54, No. 9, pp. 1529 - 1543.

Tripsas, M. (1997), 'Unraveling the process of creative destruction: Complementary assets and incumbent survival in the typesetter industry', Strategic Management Journal, Vol. 18 (Summer, Special Issue), pp. 119-142.

Ulrich, K. (1995), 'The role of product architecture in the manufacturing firm', Research Policy, Vol. 24, No. 3, pp. 419-440.

Utterback, J.M. and Acee, H.J. (2005), 'Disruptive technologies: An expanded view', International Journal of Innovation Management, Vol. 9, No. 1, pp. 1-17. 
Verganti, R. (2009), Design Driven Innovation: Changing the Rules of Competition by Radically Innovating What Things Mean, Boston, MA: Harvard Business School Publishing.

Von Hippel, E. (1986), 'Lead users: A source of novel product concepts', Management Science, Vol. 32, No. 7, pp. 791-805.

Von Hippel, E. (1998), 'Economics of product development by users: The impact of sticky local information', Management Science, Vol. 44, No. 5, pp. 629-644.

Von Hippel, E. and Von Krogh, G. (2003), 'Open source software and the private-collective innovation model: Issues for organization science', Organization Science, Vol. 14, No. 2, pp. 209223.

Von Hippel, E. (2005), Democratizing Innovation, Cambridge: The MIT Press.

Weick, K.E. (1979) The Social Psychology of Organizing, (2nd Ed.). Reading: Addison-Wesley.

Weick, K.E. and Roberts, K.H. (1993), Collective mind in organizations: Heedful interrelating on flight decks', Administrative Science Quarterly, Vol. 38, 357-381.

Wiltbank, R., Dew, N., Read, D. and Sarasvathy, S.D. (2006), 'What to do next? The case for nonpredictive strategy', Strategic Management Journal, Vol. 27, pp. 981-998.

Wright, G., van der Heijden, K., Bradfield, R., Burt, G. and Cairns, G. (2004), 'The psychology of why organizations can be slow to adapt and change', Journal of General Management, Vol. 29, No. 4, pp. 21-36.

Yu, D. and Hang C.C. (2011), 'Creating technology candidates for disruptive innovation: Generally applicable R\&D strategies', Technovation, Vol. 31, pp. 401-410.

Zeng, M. and Williamson, P.J. (2007), Dragons at Your Door: How Chinese Cost Innovation Is Disrupting Global Competition, Boston, MA: Harvard Business School Publishing.

Zhou, K. Z., Yim, C. K. and Tse, D. K. (2005), 'The effects of Strategic Orientations on Technologyand Market-Based Breakthrough Innovations', Journal of Marketing, Vol. 69, No. 2, pp. 42-60. 


\section{Internet sources:}

Denning, S. 15/02/2011. "User-Led Innovation Can't Create Breakthroughs", http://www.forbes.com/sites/stevedenning/2011/02/15/user-led-innovation-cant-createbreakthroughs/ (downloaded 10 November 2011).

Hlliday, J. 12/042011. "Tablet Sales Poised for Spectacular Growth, Claims Gartner”, http://www.guardian.co.uk/technology/2011/apr/11/tablet-ipad-sales-growth-gartner (downloaded 15 November 2011).

Shiels, M. 11/05/2011. "Google Unveils First Chrome Powered Laptops", http://www.bbc.co.uk/news/technology-13362111 (downloaded 15 November 2011).

Sorrel, 2010. "Apple Eases App Development Rules, Adobe Surges", http:/www.wired.com/gadgetlab/2010/09/apple-lifts-app-store-flash-ban-publishes-app-reviewrules/ (downloaded 14 November 2011).

Takahashi, D. (2011). "Nintendo Confirms New Console on the Way, Reports Profit Drop", http://venturebeat.com/2011/04/25/nintendo-confirms-new-console-on-the-way-reports-profitdrop/ (downloaded 14 November 2011). 
TABLE 1

A Survey of the Disruptive Innovation Literature

\begin{tabular}{|c|c|c|c|c|}
\hline Authors \& year & $\begin{array}{c}\text { DI as a supply- } \\
\text { side phenomenon }\end{array}$ & $\begin{array}{l}\text { DI as a demand- } \\
\text { side phenomenon }\end{array}$ & Key factors influencing disruptive innovation & Link to entrepreneurship \\
\hline $\begin{array}{l}\text { Christensen and } \\
\text { Bower (1996); } \\
\text { Christensen (1997) }\end{array}$ & $\sqrt{ }$ & $\sqrt{ }$ & $\begin{array}{l}\text { (1) Cognitive failures in the top level managers; (2) Existing customers' } \\
\text { demand shapes the allocation of resources in technological innovation, } \\
\text { which in turn leads to under-investment in simpler technologies for } \\
\text { emerging customers. }\end{array}$ & $\begin{array}{l}\text { Causation as the sole mode of reasoning for firms may be too } \\
\text { limited; } \\
\text { The influence of entrepreneurial customers in the society are under } \\
\text { estimated. }\end{array}$ \\
\hline $\begin{array}{l}\text { Christensen, } \\
\text { Verlinden and } \\
\text { Westerman (2002) }\end{array}$ & $\sqrt{ }$ & $\sqrt{ }$ & $\begin{array}{l}\text { Degree of firm's vertical integration or disintegration and whether } \\
\text { customers are under/over served by the functionality of products in the } \\
\text { market. }\end{array}$ & $\begin{array}{l}\text { Entrepreneurship influences a firm's organizational structure and in } \\
\text { turn its flexibility to compete with new entrants; } \\
\text { Entrepreneurial customers may be under-served. }\end{array}$ \\
\hline Adner (2002) & - & $\sqrt{ }$ & $\begin{array}{l}\text { Consumers' marginal utility from performance improvement dictates their } \\
\text { willingness to pay for product enhancements and the relationship between } \\
\text { performance overlap and symmetry. }\end{array}$ & $\mathrm{n} / \mathrm{a}$ \\
\hline $\begin{array}{l}\text { Adner and Zemsky } \\
(2006)\end{array}$ & - & $\sqrt{ }$ & $\begin{array}{l}\text { Decreasing marginal utility and consumer heterogeneity across market } \\
\text { segments affect the sustainability of competitive advantage of firms. }\end{array}$ & $\mathrm{n} / \mathrm{a}$ \\
\hline $\begin{array}{l}\text { Christensen, Suárez } \\
\text { and Utterback (1998) }\end{array}$ & $\sqrt{ }$ & - & $\begin{array}{l}\text { Firms that target new market segments with an architectural innovation will } \\
\text { tend to be more successful than those that target existing markets or } \\
\text { innovate in component technology. }\end{array}$ & The performance implications of Entrepreneurial Orientation. \\
\hline $\begin{array}{l}\text { Anderson and } \\
\text { Tushman (1990) }\end{array}$ & $\sqrt{ }$ & - & $\begin{array}{l}\text { Technological variation, selection, and retention through organizational } \\
\text { dynamics. }\end{array}$ & $\begin{array}{l}\text { Entrepreneurial dynamics, trial/error/improvisation, and } \\
\text { entrepreneurial sense making as a way of understanding the world. }\end{array}$ \\
\hline Tripsas (1997) & $\sqrt{ }$ & - & $\begin{array}{l}\text { The interaction between incumbents' investment in developing new } \\
\text { technologies, technical capabilities, and ability to appropriate the benefits } \\
\text { of technological innovation through specialized assets. }\end{array}$ & $\begin{array}{l}\text { The role of firms prior knowledge on subsequent entrepreneurial } \\
\text { discovery; } \\
\text { Tradeoffs between effectuation vs. causation influence allocation of } \\
\text { resources and capability development. }\end{array}$ \\
\hline $\begin{array}{l}\text { Henderson and Clark } \\
(1990)\end{array}$ & $\sqrt{ }$ & - & $\begin{array}{l}\text { Existing organizations are more likely to fail facing with architectural } \\
\text { innovation, which requires a reconfiguration of existing organizational and } \\
\text { technological capabilities to pursue. }\end{array}$ & $\begin{array}{l}\text { Tradeoffs between Effectuation vs. Causation influence firms' } \\
\text { strategic directions and dynamic capabilities. }\end{array}$ \\
\hline
\end{tabular}




\begin{tabular}{|c|c|c|c|c|}
\hline $\begin{array}{l}\text { Chandy and Tellis } \\
(2000)\end{array}$ & $\sqrt{ }$ & - & $\begin{array}{l}\text { Incumbents' curse is not always valid. Some incumbents may have (i) } \\
\text { dynamic organizational climates that resemble entrepreneurial small firms } \\
\text { and, (ii) strong technological capability that allows them to be aware of } \\
\text { scientific breakthroughs at an early stage. }\end{array}$ & $\begin{array}{l}\text { Tradeoffs between Effectuation vs. Causation in incumbents; but, } \\
\text { incumbents that embrace effectuation may 'see' and 'exploit' more } \\
\text { opportunities and develop 'alertness' to early stage opportunities. }\end{array}$ \\
\hline Henderson (2006) & $\sqrt{ }$ & - & $\begin{array}{l}\text { Established routines of large incumbent firms make it difficult for them to } \\
\text { sense and then act on changes in customer demand. }\end{array}$ & $\begin{array}{l}\text { The role of prior knowledge on entrepreneurial competence; the use } \\
\text { of causation as the sole strategic advantage by incumbents may be } \\
\text { too limited. }\end{array}$ \\
\hline Markides (2006) & $\sqrt{ }$ & - & $\begin{array}{l}\text { Redefinition of what an existing product or service and how it is provided } \\
\text { to customers (i.e. business model) and creation of new-to-the-world } \\
\text { products driven by supply-push force (i.e. radical product). }\end{array}$ & $\begin{array}{l}\text { The relevance of Schumpeterian rather than Kirznerian } \\
\text { entrepreneurship. }\end{array}$ \\
\hline $\begin{array}{l}\text { Utterback and Acee } \\
(2005)\end{array}$ & $\sqrt{ }$ & - & $\begin{array}{l}\text { High performing and high priced technology is introduced to the most } \\
\text { demanding established market segments and later moves toward the mass } \\
\text { market. }\end{array}$ & $\mathrm{n} / \mathrm{a}$ \\
\hline $\begin{array}{l}\text { Rao, Angelov and } \\
\text { Nov (2006) }\end{array}$ & $\sqrt{ }$ & - & $\begin{array}{l}\text { Disruptive innovation needs not necessarily be inferior in quality. } \\
\text { Technological convergence, by recombining incremental innovations, can } \\
\text { become disruptive (e.g. VOIP and P2P computing = Skype). }\end{array}$ & $\begin{array}{l}\text { The relevance of Schumpeterian rather than Kirznerian } \\
\text { entrepreneurship. }\end{array}$ \\
\hline $\begin{array}{l}\text { Zeng and Williamson } \\
(2007)\end{array}$ & $\sqrt{ }$ & - & $\begin{array}{l}\text { Cost innovation from emerging markets targeting at low-end segments of } \\
\text { developed markets in novel ways (e.g. China's manufacturer in electronics, } \\
\text { computers, medical diagnostics, automotives, etc.). }\end{array}$ & Exploitation of cross border entrepreneurial advantage \\
\hline
\end{tabular}


Figure 1

Disruptive Innovation as a co-evolutionary entrepreneurial process:

A theoretical framework
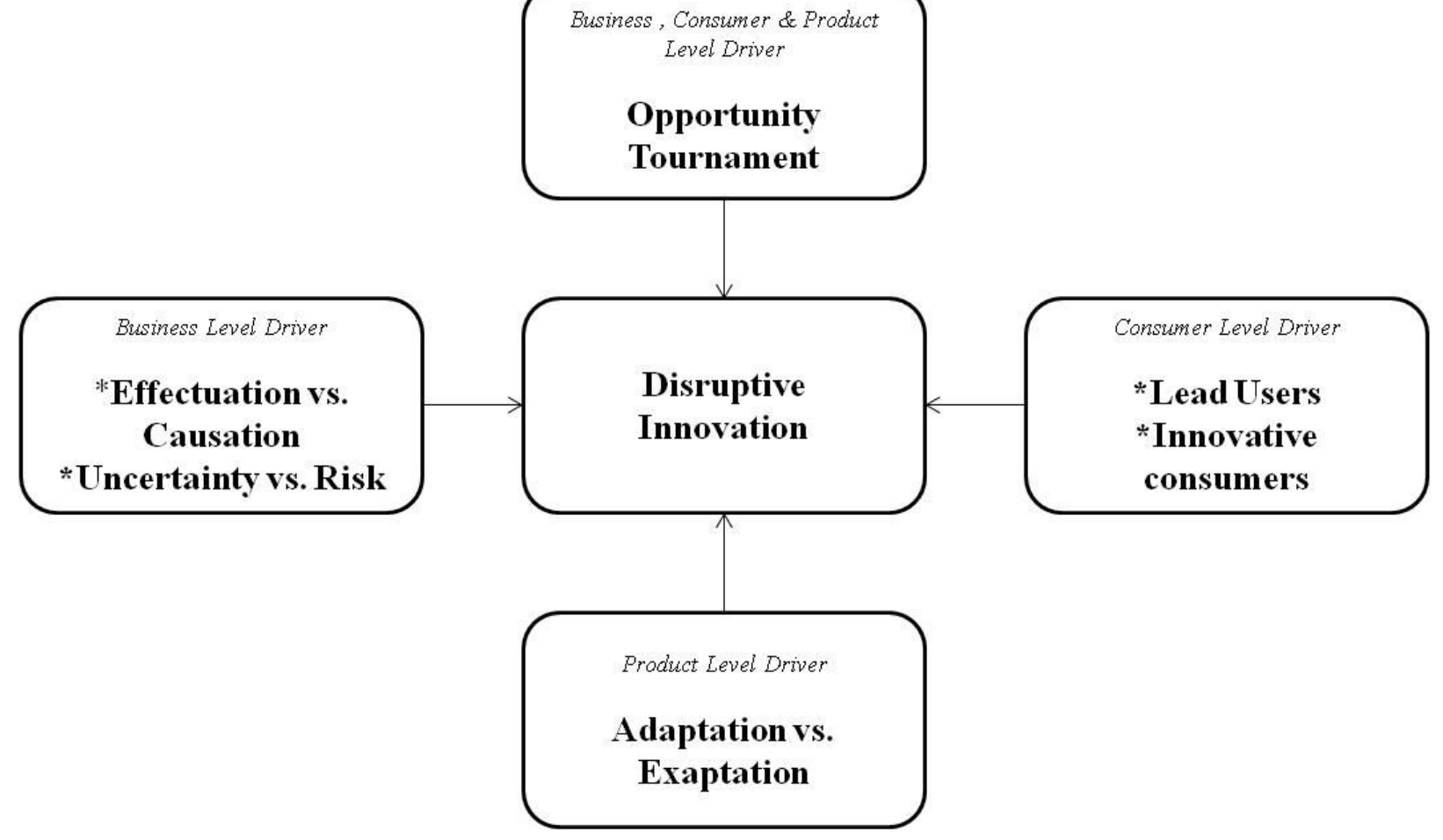